\title{
Immunolocalization of cell wall polymers in grapevine (Vitis vinifera) internodes under nitrogen, phosphorus or sulfur deficiency
}

\author{
J. C. Fernandes ${ }^{1}$ L. F. Goulao ${ }^{1,2} \cdot$ S. Amâncio ${ }^{1}$
}

Received: 10 May 2015 / Accepted: 5 April 2016

(C) The Botanical Society of Japan and Springer Japan 2016

\begin{abstract}
The impact on cell wall (CW) of the deficiency in nitrogen $(-\mathrm{N})$, phosphorus $(-\mathrm{P})$ or sulphur $(-\mathrm{S})$, known to impair essential metabolic pathways, was investigated in the economically important fruit species Vitis vinifera L. Using cuttings as an experimental model a reduction in total internode number and altered xylem shape was observed. Under $-\mathrm{N}$ an increased internode length was also seen. CW composition, visualised after staining with calcofluor white, Toluidine blue and ruthenium red, showed decreased cellulose in all stresses and increased pectin content in recently formed internodes under $-\mathrm{N}$ compared to the control. Using $\mathrm{CW}$-epitope specific monoclonal antibodies (mAbs), lower amounts of extensins incorporated in the wall were also observed under $-\mathrm{N}$ and $-\mathrm{P}$ conditions. Conversely, increased pectins with a low degree of methyl-esterification and richer in long linear 1,5-arabinan rhamnogalacturonan-I (RG-I) side chains were observed under $-\mathrm{N}$ and $-\mathrm{P}$ in mature internodes which, in the former condition, were able to form dimeric association through calcium ions. $-\mathrm{N}$ was the only condition in which 1,5-arabinan branched RG-I
\end{abstract}

Electronic supplementary material The online version of this article (doi:10.1007/s10265-016-0851-y) contains supplementary material, which is available to authorized users.

\section{S. Amâncio}

samport@isa.ulisboa.pt

1 Present Address: Instituto Superior de Agronomia, LEAF, Universidade de Lisboa, Tapada da Ajuda, 1349-017 Lisbon, Portugal

2 BioTrop, Instituto de Investigação Científica Tropical (IICT, IP), Pólo Mendes Ferrão-Tapada da Ajuda, 1349-017 Lisbon, Portugal content was not altered, as $-\mathrm{P}$ and $-\mathrm{S}$ older internodes showed, respectively, lower and higher amounts of this polymer. Higher xyloglucan content in older internodes was also observed under $-\mathrm{N}$. The results suggest that impairments of specific $\mathrm{CW}$ components led to changes in the deposition of other polymers to promote stiffening of the CW. The unchanged extensin amount observed under $-\mathrm{S}$ may contribute to attenuating the effects on the $\mathrm{CW}$ integrity caused by this stress. Our work showed that, in organized $V$. vinifera tissues, modifications in a given $\mathrm{CW}$ component can be compensated by synthesis of different polymers and/or alternative linking between polymers. The results also pinpoint different strategies at the $\mathrm{CW}$ level to overcome mineral stress depending on how essential they are to cell growth and plant development.

Keywords Cell wall epitopes · Cellulose $\cdot$ Mineral stress · Pectin $\cdot$ Xyloglucan

$\begin{array}{ll}\text { Abbreviations } & \\ \text { CBM } & \text { Carbohydrate binding module } \\ \text { CW } & \text { Cell wall } \\ \text { EXT } & \text { Extensin } \\ \text { GH9C } & \text { Glycosyl hydrolase family 9C } \\ \text { HG } & \text { Homogalacturonan } \\ \text { I-1 } & \text { Top internode } \\ \text { I-4 } & \text { Fourth internode } \\ \text {-N } & \text { Absence of nitrogen } \\ \text { mAbs } & \text { Monoclonal antibodies } \\ \text {-P } & \text { Absence of phosphorous } \\ \text { PBS } & \text { Phosphate buffered saline } \\ \text { RG-I and -II } & \text { Rhamnogalacturonans I and II } \\ - \text { S } & \text { Absence of sulfur } \\ \text { XyG } & \text { Xyloglucan }\end{array}$




\section{Introduction}

The plant capacity for upright growth and penetration into the soil comes from the high organ mechanical robustness conferred by semi-rigid and cemented together cell walls (CW). CWs also provide plants with the necessary strength and plasticity to resist adverse environmental conditions.

The properties, structural integrity, and simultaneous strength and flexibility of the plant $\mathrm{CW}$ depends on changes in composition and complex arrangement of its polymers throughout growth and differentiation processes (Braidwood et al. 2014). Two types of CW differing in function and composition can be formed. Primary CWs surround dividing cells allowing extensibility during organ growth, while after growth ceases a thicker secondary wall may be deposited (Lee et al. 2011). The frontier between the two types of CW is not clear cut, but rather a continuum, when based on structure and architecture (Albersheim et al. 2010; Knox 2008).

Several polysaccharides compose the CW. Primary walls are comprised of $15-40 \%$ cellulose, $30-50 \%$ pectins and 20-30\% hemicelluloses, predominantly xyloglucans (XyGs), on a dry weight basis (Cosgrove and Jarvis 2012). Together with these major polymers, lower amounts of structural glycoproteins, phenolic esters, ionically and covalently bound minerals and enzymes are present (Cosgrove and Jarvis 2012). Cellulose forms long, rigid crystalline microfibrils of 1,4-linked $\beta$-D-glucose residues that provide the major load-bearing role of $\mathrm{CW}$ (Brashline et al. 2014; Cosgrove 2005). The hemicellulose class consists of several types of branched polysaccharides that include XyGs, xylans, mannans, and mixed-linkage glucans (Scheller and Ulvskov 2010). Hemicelluloses are structurally homologous to cellulose since their backbones are composed of 1,4-linked $\beta$-D-hexosyl residues. This property suggested coating and tethering to cellulose microfibrils to form a load-bearing network (Cosgrove 2000). However, the capacity of XyG-cellulose binding to confer sufficient strength to withstand the tensile forces in the $\mathrm{CW}$ has been challenged (Thompson 2005). Moreover, Arabidopsis mutants defective in XyG displayed only moderate growth impairment (Cavalier et al. 2008; Zabotina et al. 2012). A model in which $\mathrm{XyG}$ is restricted within the $\mathrm{CW}$ and intertwined with cellulose only at limited sites forming selective targets for CW loosening, the so called "biomechanical hotspots" theory, was recently proposed (Park and Cosgrove 2012, 2015). Three classes of pectic polysaccharides containing 1,4-linked $\alpha$-D-galacturonic acid have been characterized: linear homogalacturonans (HGs), branched rhamnogalacturonans (RG-I and -II) and substituted galacturonans. Pectic polysaccharides are particular targets for enzymatic modulation through methyl or acetyl de-esterification of $\mathrm{HG}$ chains that can dramatically influence $\mathrm{CW}$ properties and assembly, affecting cell adhesion porosity and hydration (Lionetti et al. 2007; Peaucelle et al. 2008; Pelloux et al. 2007). Recently a role for enzymatic modulation of pectin polymer size in $\mathrm{CW}$ expansion was demonstrated (Xiao et al. 2014).

These new findings have been challenging $\mathrm{CW}$ architecture models. It was recently hypothesized that linkages between pectins and xylans may control mechanical properties in the XyG-deficient walls (Park and Cosgrove 2012; Zabotina et al. 2012). As cellulose-XyG hydrogen bonds are the major targets for expansin action and CW extensibility, the reduction of their frequency makes these walls mechanically weaker and simultaneously less extensible. Evidence for covalent linkages between side-chains of specific pectin polysaccharides and cellulose microfibrils (Zykwinska et al. 2007) and XyG molecules (Popper and Fry 2008) have been reported, further supporting these assumptions.

Although present in lower amounts in the $\mathrm{CW}$ of vascular plants, extensins (EXT), a family of structural hydroxyproline-rich glycoproteins (HRGPs) (Showalter 1993), were demonstrated to have a key role during cell expansion and growth (Cannon et al. 2008; Lamport et al. 2011; Ringli 2010) and to be required for normal wall architecture and function in development, particularly during polarized cell expansion (Velasquez et al. 2011, 2012). Despite the high number of proteins with EXT domains found in plants (Lamport et al. 2011), little is known about their function and how this protein diversity is coordinated during plant development (Hijazi et al. 2014).

Although knowledge on the biochemical structure of cellulose, hemicelluloses and pectins is largely available, the organization and interactions between these components and other molecules in the $\mathrm{CW}$ is poorly known and the type and extent of $\mathrm{CW}$ changes that are associated with the plant's capacity to interact with the environment and cope with abiotic stresses has been insufficiently investigated. A great variety of CWs have been described at the molecular level. Impacting the overall dynamics and modulating development does not require dramatic restructuring of the entire CW. Changes in composition and structure are often occur specifically localized to a small number and type of cells. The sensitivity and resolution of chemical quantification methods neither provide accurate measurement nor information about alterations in the architecture of $\mathrm{CW}$ polymers. Immunohistochemical techniques enable localization of $\mathrm{CW}$ epitopes in situ within complex tissues, overcoming this limitation. In the last two decades, over 150 molecular probes targeting at the cellular level have been developed (Knox 2008; Moller et al. 2008; Pattathil et al. 2010; Ralet et al. 2010). The distribution of carbohydrate epitopes in plant $\mathrm{CWs}$ can be selectively recognized by several monoclonal antibodies (mAbs) and carbohydrate 
binding modules (CBMs) (Lee et al. 2011), allowing direct in muro visualization. Following immunolocalization approaches, several detailed aspects of $\mathrm{CW}$ heterogeneity including the importance of specific pectin methylation patterns on cell adhesion (Ordaz-Ortiz et al. 2009; Willats et al. 2001), or localized changes in precise CW polymers in response to abiotic stresses (Liu et al. 2014; Muszynska et al. 2014) have been disclosed. The knowledge acquired hastens our ability to relate $\mathrm{CW}$ structures to cell biological events and integration of this information into the emerging understanding of polymer functions (Knox 2008).

Using $V$. vinifera callus developing under depletion of major nutrients, nitrogen, phosphorus or sulfur, we previously reported reorganization of specific $\mathrm{CW}$ components in response to individual nutrient deprivation. Decreased cellulose, modifications in pectin methyl-esterification, increase of structural proteins and tighter association of polysaccharides were observed in the $\mathrm{CW}$, although to different degrees according to the specific stress imposed (Fernandes et al. 2013). Under nitrogen and, to a lower extent, under phosphorus deficiency, we hypothesize that cellulose reduction could be counterbalanced by modifications in matrix polymers to maintain tissue integrity. However, callus are plant dedifferentiated tissues, so may behave differently to organized tissues. The aim of the present work was to investigate $\mathrm{CW}$ responses, specifically components rearrangement, to the depletion of the same individual major nutrients, using grapevine shoot internodes organized tissues as experimental model. For that purpose immunolocalization assays were performed to investigate $V$. vinifera $\mathrm{CW}$ responses to specific mineral depletion.

\section{Materials and methods}

\section{Plant material and stress imposition}

Grapevine ( $V$. vinifera $\mathrm{L}$.) cv. Trincadeira pruned wood cuttings were treated with fungicide $(2 \% \mathrm{w} / \mathrm{v}$, Benlate) and stored at $4{ }^{\circ} \mathrm{C}$ for 2 months. Rooting and shoot elongation took place in $30 \%$ nutrient solution (Knight and Knight 2001) in the dark, at $25 \pm 2{ }^{\circ} \mathrm{C}$. When shoots had developed four internodes they were transferred to $3 \mathrm{~L}$ pots filled with vermiculite in greenhouse under an irradiance of $200 \mu \mathrm{mol} \mathrm{m}{ }^{-2} \mathrm{~s}^{-1}, 16 \mathrm{~h}$ photoperiod, day/night temperature of $25 \pm 2 / 23 \pm 2{ }^{\circ} \mathrm{C}$ and relative humidity of ca. $60 \%$. Four experimental conditions were set up: weekly watering with full nutrient solution (control), nitrogen deficiency $(-\mathrm{N})$, phosphorus deficiency $(-\mathrm{P})$ or sulfur deficiency $(-\mathrm{S})$ (Table S1). Shoot internode number and length of the fourth internode from the top (I-4) were recorded weekly for 8 weeks. I-4 and the top internode (I-1) were collected at the 6th week for histological staining and immunohistochemical analysis.

\section{Cross sectioning}

Internode samples of about $1 \mathrm{~cm}$ in length were vacuum infiltrated and fixed overnight in $4 \%$ (v/v) paraformaldehyde solution in $1 \times$ sodium phosphate buffer $(\mathrm{pH} 7.4)$ and dehydrated in a graded ethanol series. Absolute ethanol was substituted by an ethanol:limonen (1:1) solution (Histo-Clear II; National Diagnostics) for $1 \mathrm{~h}$ and replaced three times by $100 \%$ Histo-clear for $1 \mathrm{~h}$ each. The samples were then infiltrated with $50 \%$ paraffin (Histosec, Merck) $50 \%$ Histo-clear solution overnight at $58{ }^{\circ} \mathrm{C}$ and spacing in $100 \%$ Histosec for 2 days, replaced twice a day. Embedded tissues were casted with Histosec. Five micrometers thick sections were prepared using a Meditome M530 (Medite) micrometer and collected on poly-L-lysine coated microscope slides. Paraffin removal was accomplished as described by Nic-Can et al. (2013).

\section{Histological staining}

Sections were stained with aqueous $1 \%(\mathrm{w} / \mathrm{v})$ toluidine blue (Sigma, St. Louis, MO) or $0.05 \%(\mathrm{w} / \mathrm{v})$ ruthenium red dye (Sigma, St. Louis, MO) for $5 \mathrm{~min}$, rinsed twice with distilled water for $30 \mathrm{~min}$, mounted in water and observed under light microscopy. Similar sample sections were stained with $0.1 \%(\mathrm{w} / \mathrm{v})$ calcofluor White fluorescent brightener (Sigma, St. Louis, MO). Images were observed undera Leitz Laborlux S epifluorescence microscope with the objectives Leitz Phaco 1 10X and Leitz Fluoreszenz $63 \mathrm{x}$ and for calcofluor stained sections, with filters 365/445 Nm. Images were acquired with a Zeiss AxioCam digital camera and analyzed using the ImageJ 1.48 package (http://imagej.nih.gov/ij/). The xylem vessel diameter ratio (ratio between the longer and its shorter diameter) and vessel area were measured.

\section{Immunolocalization analysis}

Immunolocalization assays were performed using PAM1, 2F4, LM6, LM13, LM15 and LM1 mAbs which target polymer and recognition region are presented in Table S2. De-paraffinated and rehydrated sections were blocked with $5 \%$ (w/v) non-fat milk in $0.1 \mathrm{M}$ phosphate-buffered saline (PBS, $\mathrm{pH}$ 7.2) for $30 \mathrm{~min}$ at room temperature. The sections were then incubated with each of the primary antibodies under appropriate dilutions (1:250 for 2F4, 1:10 for LM6, LM13, LM15 and LM1, 1:5 for PAM1) in blocking solution overnight at $4{ }^{\circ} \mathrm{C}$. 2F4, LM6, LM13, LM15 and LM1 hybridized sections 
were rinsed and incubated with secondary anti-rat or anti-mouse IgG/FITC (Sigma-Aldrich, St Louis, MO, USA) diluted 1:30 in blocking solution for $4 \mathrm{~h}$ at room temperature in the dark. For PAM1 detection, the AntiHIS (Sigma-Aldrich, St Louis, MO, USA) was used as secondary antibody for $2 \mathrm{~h}$ at 1:100 dilution followed by incubation with a tertiary antibody anti-mouse/FITC (1:50) for additional $2 \mathrm{~h}$. The sections were then rinsed with PBS and briefly incubated in $1 \%$ (w/v) Calcofluor white and further rinsed. Finally, sections were mounted with glycerol/PBS-based anti-fade solution (SlowFade Antifade Kit; Life Technologies) according to the manufacture recommendations. Images were observed under a Leitz Laborlux S epifluorescence microscope with the objective Leitz Phaco 1 10X and Leitz Fluoreszenz 63x and filters 470/525 and acquired using a Zeiss AxioCam digital camera. Single layer or simultaneously visualized images were analyzed using the ImageJ 1.48 package (http://imagej.nih.gov/ij/). Negative controls for each mAb (Fig. S1), where primary antibodies were omitted confirmed the absence of unspecific labelling (Coimbra et al. 2007). ImageJ 1.48 package was also used to measure the number of green pixels from 50 individual specifically labelled spots in 3 independent images after subtracting the number of pixels obtained in equivalent spots of the negative controls.

\section{Data analysis}

Data is presented as mean values \pm standard deviation (SD) of an appropriate number of replicates for each assay. The results were statistically evaluated by variance analysis (ANOVA) and post hoc Bonferroni test with a $\mathrm{p}<0.01$ significance level, to compare the significance of each treatment effect. The SigmaPlot (Systat Software Inc.) statistical package was used.

\section{Results}

\section{Growth under mineral deficiency}

Growth parameters were recorded to assess the effect of the imposed conditions on the cutting development, for validating the grapevine cuttings as experimental model. As observed in Fig. 1, individual mineral stress $(-\mathrm{N},-\mathrm{P},-\mathrm{S})$ altered the normal growth of $V$. vinifera cuttings. Mineral depletion significantly reduced the number of internodes from the 4th week (Fig. 1a), with a more pronounced effect under $-\mathrm{N}$ and $-\mathrm{P}$. The length of the fourth internode (I-4) was also affected by $-\mathrm{N}$ conditions, which contributed to a significant increase when compared to the other conditions (Fig. 1b).

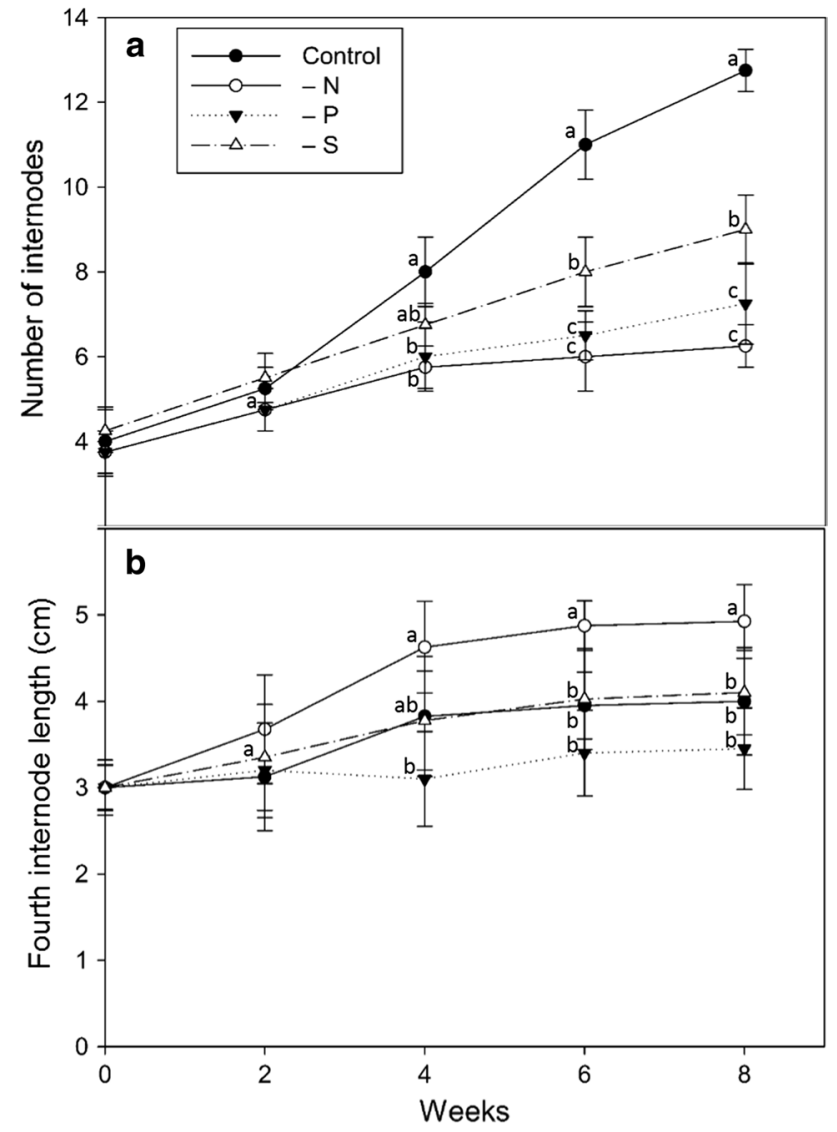

Fig. 1 Average number of shoot internodes (a) and length of the fourth internode (b) of $V$. vinifera cuttings grown under complete nutrient medium (control), and in the absence of nitrogen $(-\mathrm{N})$, phosphorus $(-\mathrm{P})$ and sulfur $(-\mathrm{S})$. Values are the mean $\pm \mathrm{SD}$ of at least three measurements. Different letters in each time point indicate statistically significant differences at $p<0.01$

\section{Internode anatomy}

The average diameter ratio and the area of xylem vessels are presented in Table 1 . In $-\mathrm{N}$ I-1 and $-\mathrm{S}$ I-4 nodes both parameters were not distinct from the control. Conversely $\mathrm{I}-1$ xylem vessels produced under $-\mathrm{P}$ and $-\mathrm{S}$ and xylem vessels from $\mathrm{I}-4-\mathrm{N}$ and $-\mathrm{P}$ nodes were more elliptical in shape than in the control. Concerning xylem area, this parameter was higher than the control in $-\mathrm{P}$ and $-\mathrm{S}$ in the recently formed internodes $\mathrm{I}-1$, but significantly reduced comparing to control in -N and -P I-4 nodes (Table 1). These structural differences promoted by the absence of specific nutrients were reflected also in the integrity of the older tissues. While in I-1 all tissues are structurally visible, in I-4, some structures were damaged during sectioning, namely the pith, the vascular bundles and the cortical parenchyma (Fig. 2, arrows), suggesting a more pronounced structural weakening in tissues developed under mineral deficiency (Fig. 2). 
Table 1 Measured xylem vessel diameter ratio (ratio between the longer and its shorter diameter) and area of $V$. vinifera shoots top (I-1) and fourth (I-4) internode after 6 weeks growth in complete nutrient solution (control) and in the absence of nitrogen $(-\mathrm{N})$, phosphorus $(-\mathrm{P})$ and sulfur $(-\mathrm{S})$

\begin{tabular}{lccrrrr}
\hline & & Control & $-\mathrm{N}$ & $-\mathrm{P}$ & $-\mathrm{S}$ \\
\hline Xylem vessel diameter ratio & $\mathrm{I}-1$ & $1.18^{\mathrm{b}} \pm 0.12$ & $1.20^{\mathrm{b}} \pm 0.16$ & & $1.30^{\mathrm{a}} \pm 0.17$ & $1.38^{\mathrm{a}} \pm 0.19$ \\
& $\mathrm{I}-4$ & $1.18^{\mathrm{b}} \pm 0.18$ & $1.37^{\mathrm{a}} \pm 0.21$ & $1.24^{\mathrm{a}} \pm 0.09$ & $1.21^{\mathrm{ab}} \pm 0.18$ \\
& $\mathrm{I}-1$ & $519.94^{\mathrm{c}} \pm 119.80$ & $439.94^{\mathrm{c}} \pm 107.43$ & $696.80^{\mathrm{b}} \pm 91.76$ & $1549.98^{\mathrm{a}} \pm 224.45$ \\
Xylem vessel area $\left(\mu \mathrm{m}^{2}\right)$ & $\mathrm{I}-4$ & $2668.20^{\mathrm{a}} \pm 631.32$ & $1262.64^{\mathrm{b}} \pm 236.57$ & $1632.55^{\mathrm{b}} \pm 192.77$ & $3205.90^{\mathrm{a}} \pm 486.79$ \\
& &
\end{tabular}

Values are the mean \pm SD of 20 random measurements

Different letters in each row indicate statistically significant differences at $P<0.01$

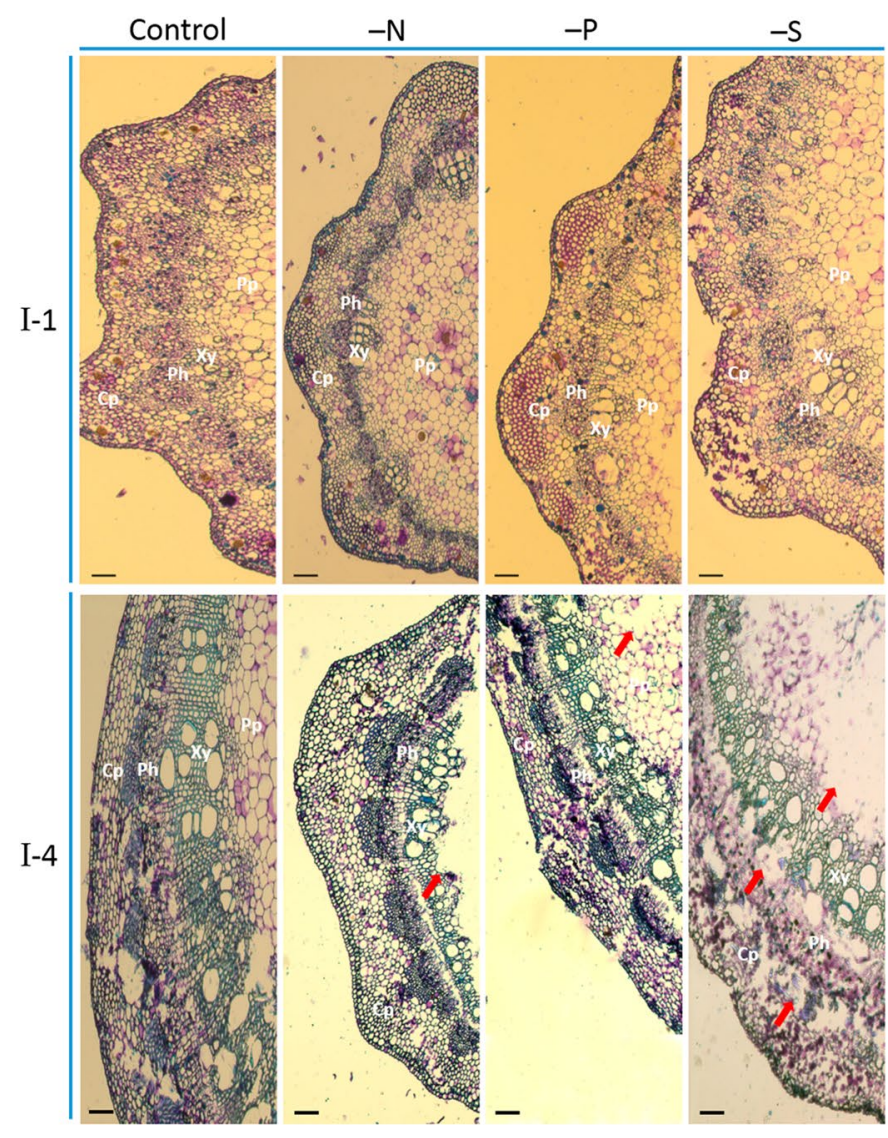

Fig. 2 Toluidine blue and ruthenium red histological staining of $V$. vinifera top (I-1) and fourth (I-4) internode sections obtained after 6 weeks growth under control and $-\mathrm{N},-\mathrm{P}$ and $-\mathrm{S}$ conditions. Images were acquired under the same exposition time for all treat-

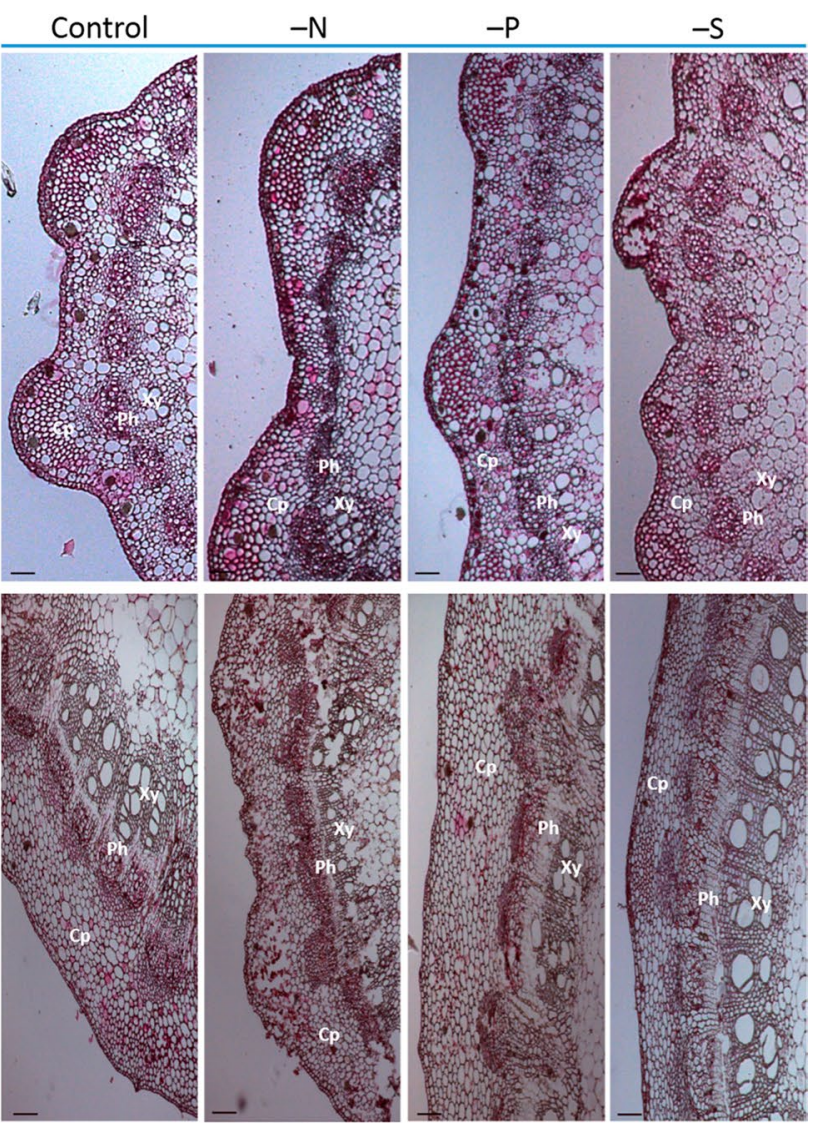

ments. Arrows indicate structures with compromised integrity. $X y$ xylem, $P h$. phloem, $C p$ cortical parenchyma, $P p$ pith parenchyma. Bar scale $=50 \mu \mathrm{m}$

a reduction of the toluidine blue staining was observed in the same region while in $-\mathrm{S}$ phloem cells a reduction of the ruthenium staining was observed. Toluidine blue also binds to lignin, producing a characteristic blue staining. The absence of nitrogen led to an increased blue staining in the I-1 xylem cells, suggesting increased lignin content. Calcofluor white readily binds to cellulose and other B-linked glucans. The absence of minerals in the nutrient stained, both in I-1 and I-4 with both dyes. In I-1 under -P, 
Fig. 3 Histological staining of pectic polysaccharides and lignin (toluidine blue), pectic polysaccharides (ruthenium red) and cellulose (calcofluor white) of the V. vinifera top (I-1) and fourth (I-4) internodes after 6 weeks growth under control and $-\mathrm{N},-\mathrm{P}$ and $-\mathrm{S}$ conditions. Images were acquired under the same exposition time for all treatments. $X y$ xylem, $P h$ phloem. Bar scale $=20 \mu \mathrm{m}$

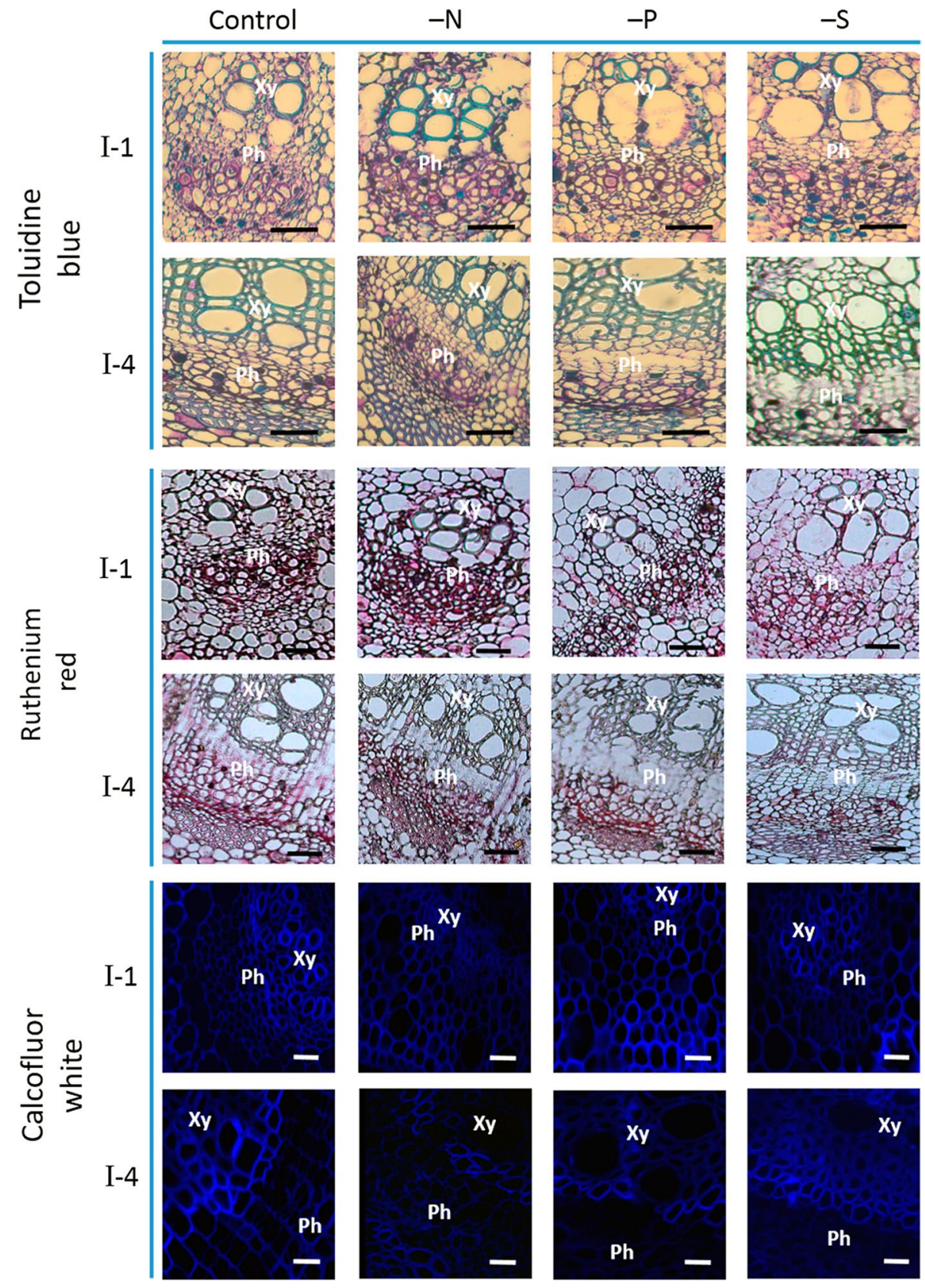

solution resulted, in both internodes, in a reduced intensity of calcofluor staining (Table 2). This reduction was more pronounced in samples developing under nitrogen starvation. A reduction in the calcofluor white staining between I-1 and I-4 under $-\mathrm{N}$ and -P conditions was also observed, in an opposite trend to the observations in control cuttings (Fig. 3; Table 2).

\section{In situ localization of $\mathrm{CW}$ epitopes}

To get insight on how the structural arrangement of CW polymers is modified under mineral stress conditions, a set of mAbs specific to selected epitopes was used to probe $V$. vinifera internode cross sections. PAM1 (Willats et al. 1999), specific to long stretches of unesterified $\mathrm{HG}$, was used to investigate the extent to which each mineral stress affected the distribution of those stretches in pectins. Except under $-\mathrm{S}$, the amount of low methylesterified pectins increased in the cortical parenchyma of both internodes, compared to the control (Fig. 4; Table 2). These long stretches of unesterified HGs are known to be able to dimerise. This biochemical event was investigated by observing the labeling pattern of the 2F4 (Liners et al. 1989) antibody. The signal pattern was altered only under $-\mathrm{N}$, although in opposite trends in both internodes investigated. While younger material showed a decreased 
Table 2 Number of pixels quantified in the images of $V$. vinifera section of the top (I-1) and fourth (I-4) internodes developed under each individual mineral stress $(-\mathrm{N},-\mathrm{P}$ and $-\mathrm{S})$ and control conditions after hybridization using 2F4, PAM1, LM6, LM13, LM15 and LM1 antibodies and calcofluor labelling

\begin{tabular}{|c|c|c|c|c|c|}
\hline & & Control & $-\mathrm{N}$ & $-\mathrm{P}$ & $-\mathrm{S}$ \\
\hline \multirow[t]{2}{*}{ Calcofluor white } & $\mathrm{I}-1$ & $161.30^{\mathrm{a}} \pm 13.13$ & $115.80^{c} \pm 15.09$ & $130.45^{\mathrm{b}} \pm 11.12$ & $127.10^{\mathrm{bc}} \pm 7.20$ \\
\hline & $\mathrm{I}-4$ & $194.40^{\mathrm{a}} \pm 20.68$ & $97.60^{c} \pm 11.27$ & $108.35^{\mathrm{bc}} \pm 18.71$ & $123.30^{b} \pm 25.32$ \\
\hline \multirow[t]{2}{*}{ PAM1 } & $\mathrm{I}-1$ & $31.50^{\mathrm{b}} \pm 4.72$ & $91.75^{\mathrm{a}} \pm 7.64$ & $86.45^{\mathrm{a}} \pm 7.27$ & $23.55^{\mathrm{c}} \pm 5.93$ \\
\hline & $\mathrm{I}-4$ & $23.90^{c} \pm 4.14$ & $89.60^{\mathrm{a}} \pm 9.97$ & $45.45^{\mathrm{b}} \pm 6.43$ & $20.90^{c} \pm 3.14$ \\
\hline \multirow[t]{2}{*}{$2 \mathrm{~F} 4$} & $\mathrm{I}-1$ & $40.75^{\mathrm{ab}} \pm 6.66$ & $15.40^{\mathrm{c}} \pm 2.08$ & $35.35^{\mathrm{b}} \pm 3.95$ & $50.90^{\mathrm{a}} \pm 4.08$ \\
\hline & I-4 & $28.00^{\mathrm{b}} \pm 3.49$ & $51.95^{\mathrm{a}} \pm 4.83$ & $31.10^{\mathrm{b}} \pm 4.37$ & $26.65^{\mathrm{b}} \pm 3.63$ \\
\hline \multirow[t]{2}{*}{ LM6 } & $\mathrm{I}-1$ & $140.05^{\mathrm{d}} \pm 9.16$ & $174.35^{\mathrm{b}} \pm 7.61$ & $151.05^{\mathrm{c}} \pm 4.28$ & $195.70^{\mathrm{a}} \pm 7.88$ \\
\hline & $\mathrm{I}-4$ & $110.60^{b} \pm 4.86$ & $110.25^{\mathrm{b}} \pm 7.39$ & $79.35^{\mathrm{c}} \pm 7.23$ & $137.2^{\mathrm{a}} \pm 5.48$ \\
\hline \multirow[t]{2}{*}{ LM13 } & $\mathrm{I}-1$ & $2.05^{\mathrm{b}} \pm 3.83$ & $17.85^{\mathrm{a}} \pm 5.74$ & $19.15^{\mathrm{a}} \pm 6.00$ & $17.00^{\mathrm{a}} \pm 5.70$ \\
\hline & $\mathrm{I}-4$ & $136.45^{\mathrm{c}} \pm 10.36$ & $157.35^{\mathrm{a}} \pm 11.37$ & $145.25^{\mathrm{b}} \pm 8.95$ & $137.70^{\mathrm{bc}} \pm 9.87$ \\
\hline \multirow[t]{2}{*}{ LM15 } & $\mathrm{I}-1$ & $129.20^{c} \pm 7.78$ & $211.10^{\mathrm{a}} \pm 13.23$ & $171.70^{\mathrm{b}} \pm 8.54$ & $148.80^{c} \pm 10.63$ \\
\hline & $\mathrm{I}-4$ & $45.75^{\mathrm{b}} \pm 6.70$ & $75.95^{\mathrm{a}} \pm 8.12$ & $46.65^{\mathrm{b}} \pm 7.83$ & $41.40^{\mathrm{b}} \pm 5.92$ \\
\hline \multirow[t]{2}{*}{ LM1 } & $\mathrm{I}-1$ & $16.65^{\mathrm{a}} \pm 3.54$ & $15.75^{\mathrm{a}} \pm 4.11$ & $16.05^{\mathrm{a}} \pm 4.14$ & $16.15^{\mathrm{a}} \pm 4.28$ \\
\hline & $\mathrm{I}-4$ & $145.45^{\mathrm{a}} \pm 9.66$ & $136.20^{\mathrm{b}} \pm 6.87$ & $125.65^{\mathrm{c}} \pm 8.99$ & $143.45^{\mathrm{a}} \pm 7.66$ \\
\hline
\end{tabular}

Data are presented as mean $\pm \mathrm{SD}$ of the number of pixels from 50 individual specifically labelled spots in three independent images after subtracting the number of pixels obtained in equivalent spots of the negative controls (Fig. S1)

Different letters in the same row indicate significant differences at $P<0.01$
Fig. 4 In situ localization of 2F4, PAM1 reactive homogalacturonan epitopes of $V$. vinifera top (I-1) and fourth (I-4) internodes after 6 weeks growth in complete nutrient medium (control) and in the absence of nitrogen $(-\mathrm{N})$, phosphorus $(-\mathrm{P})$ and sulfur $(-\mathrm{S})$. Samples were also stained with Calcofluor white to reveal anatomical details. 2F4, PAM1 signals are shown in green. Arrows highlight regions where specific labeling occurs. No label localized on the $\mathrm{CW}$ was observed when primary antibodies were omitted from control sections (Fig. S1). Images were taken under the same exposition time for all treatments. $X y$ xylem, $P h$ phloem, $C p$ cortical parenchyma. Bar scale $=20 \mu \mathrm{m}$

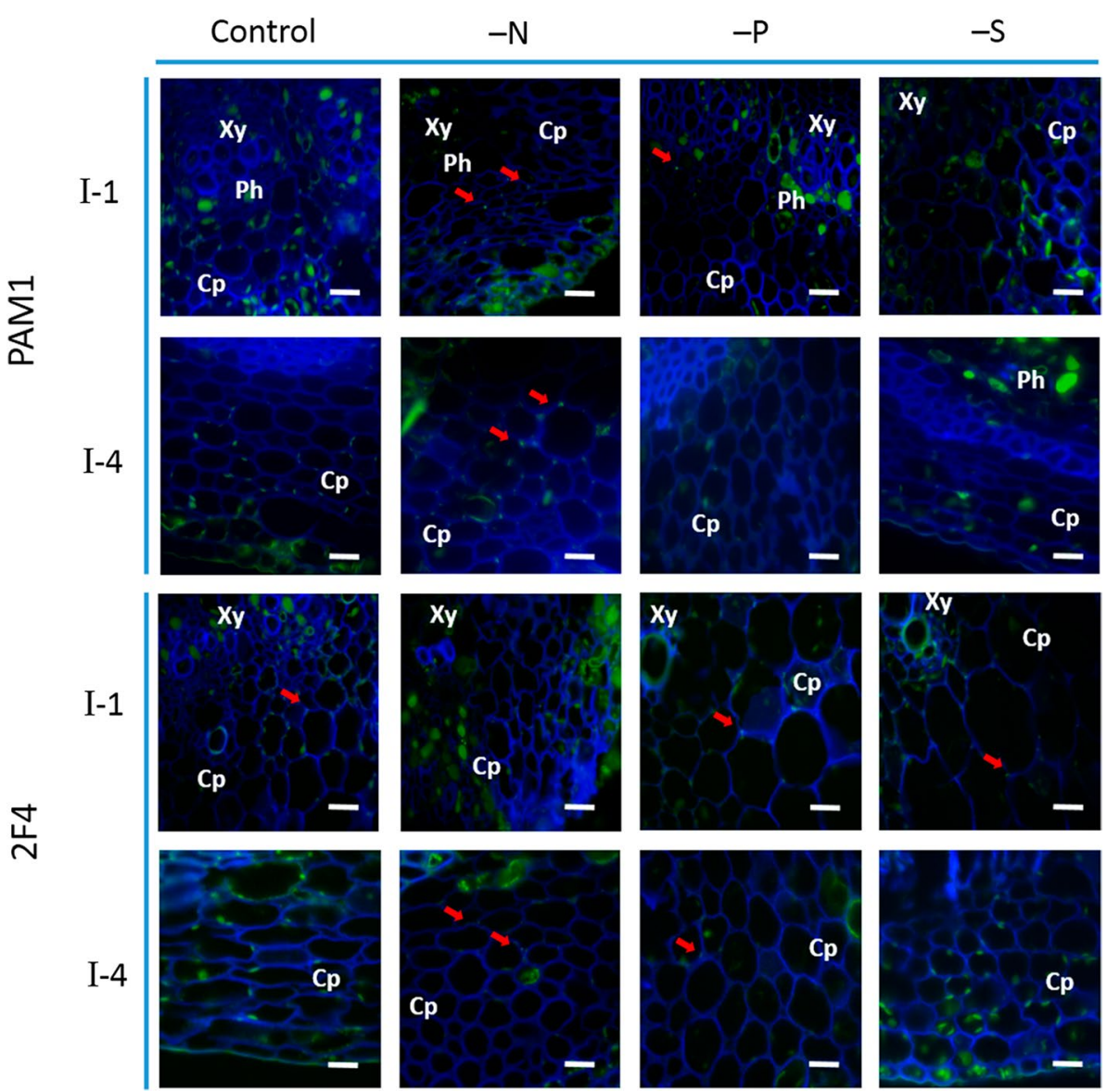

labelling, an increase relative to controls was observed in I-4 (Fig. 4; Table 2). Recognition of these low methylesterified pectins by both PAM1 and 2F4 antibodies was restricted to cell corners (Fig. 3, arrows). LM6 was used to probe (1-5)- $\alpha$-L-arabinans (Willats et al. 1998). In the present experimental system pectic arabinan is mainly 
Fig. 5 In situ localization of LM6 and LM13, reactive pectic arabinans epitopes of $V$. vinifera top (I-1) and fourth (I-4) internodes after 6 weeks growth in complete nutrient medium (control) and in the absence of nitrogen $(-\mathrm{N})$, phosphorus $(-\mathrm{P})$ and sulfur $(-S)$. Samples were also stained with Calcofluor white to reveal anatomical details. LM6 and LM13 signals are shown in green. Arrows highlight regions where specific labeling occurs. No label localized on the CW was observed when primary antibodies were omitted from control sections (Fig. S1). Images were taken under the same exposition time for all treatments. $X y$ xylem, $P h$ phloem, $C p$ cortical parenchyma. Bar scale $=20 \mu \mathrm{m}$

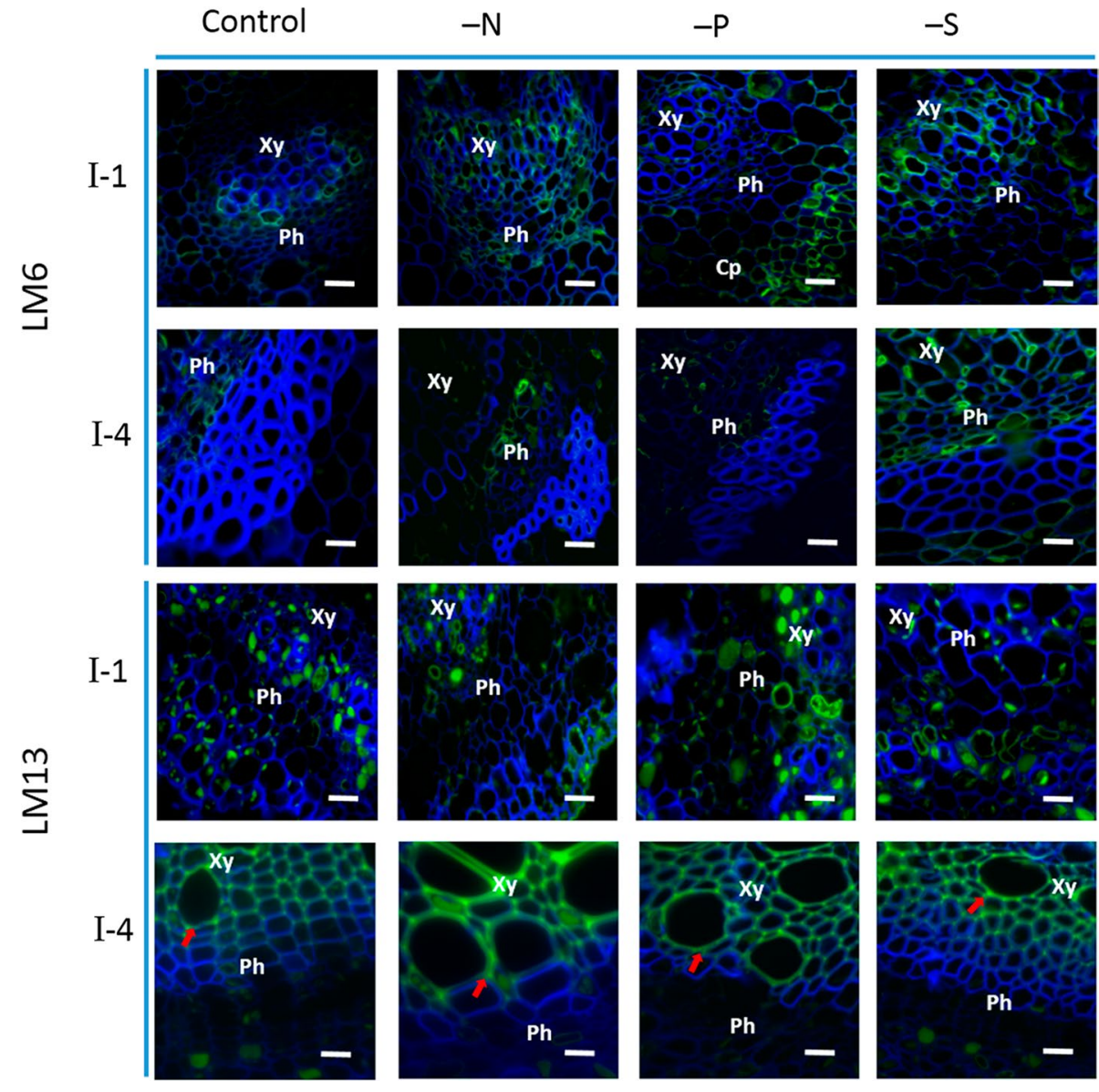

present in I-1 xylem cells. In -N I-1 an increase of pectic arabinans was observed while under phosphorus depletion, an increased labeling was observed in the cortical parenchyma. In the I-4 internode the labeling of LM6 increased under -S (Fig. 5; Table 2; Fig. S1). LM13 (Moller et al. 2008) binds preferentially to long oligoarabinosides from RG-I side branches. Although a low intensity in the CWs from I-1 was observed, under nutrient starvation, the signal was increased with a similar degree for all conditions (Fig. 5; Table 2; Fig. S1). Conversely, in I-4, specific labelling was significantly stronger that in $\mathrm{I}-1$ and increased in result of $-\mathrm{N}$ and $-\mathrm{P}$, but not $-\mathrm{S}$ conditions. Specific $\mathrm{CW}$ signal was only detected in the xylem (Fig. 5 arrow; Table 2; Fig. S1).

The LM15 (Marcus et al. 2008) antibody was used to probe $\mathrm{XyG}$, the major hemicellulose present in primary CWs of dicots. As observed in Fig. 6, in recently formed internodes LM15-labelling was restricted to the phloem and to some xylem cells. In I-4, LM15 labeling intensity was significantly lower than in I-1 for all conditions and additionally detected in the parenchyma cells but generally absent from xylem cells. Concerning responses triggered by the absence of nutrients, $-\mathrm{N}$ and $-\mathrm{P}$ cuttings showed increased LM15-labelling in the I-1 phloem CW, while in the I-4 the effect was observed only in result of the former stress, and extended to cortical parenchyma cells (Fig. 6; Table 2). Under mineral stress LM15 localization was observed in the walls of I-4 internode cortical parenchyma, as suggested by the increased labelling observed at some cell junctions and center of the adhesion plan (Fig. 7). Extensins were labelled with low intensity and independent of the stress imposed in the top internodes. In I-4, LM1 (Smallwood et al. 1995), a specific antibody for EXT, was detected only in xylem vessels and showed less intense signal in response to the absence of phosphorus and nitrogen, although with a less pronounced response in the later (Fig. 6; Table 2; Fig. S1).

\section{Discussion}

Plant growth, development and production respond to environmental variation, influencing the plant phenotype. Due to its involvement in essential metabolic pathways, nitrogen $(\mathrm{N})$, phosphorus $(\mathrm{P})$ or sulfur $(\mathrm{S})$ have a marked effect on plant growth and productivity. As expected $\mathrm{N}$ deficiency affects directly many biological processes, including the amino acid, nucleic acids, other $\mathrm{N}$-containing 
Fig. 6 In situ localization of LM15, reactive xyloglucan epitopes and LM1, reactive extensin epitope of $V$. vinifera top (I-1) and fourth (I-4) internodes after 6 weeks growth in complete nutrient medium (control) and in the absence of nitrogen $(-\mathrm{N})$, phosphorus $(-\mathrm{P})$ and sulfur $(-\mathrm{S})$. Samples were also stained with Calcofluor white to reveal anatomical details. LM15 and LM1 signals are shown in green. Arrows highlight regions where altered LM15 pattern labeling occurs. No label localized on the CW was observed when primary antibodies were omitted from control sections (Fig. S1). Images were taken under the same exposition time for all treatments. $X y$ xylem, $P h$ phloem, $C p$ cortical parenchyma. Bar scale $=20 \mu \mathrm{m}$

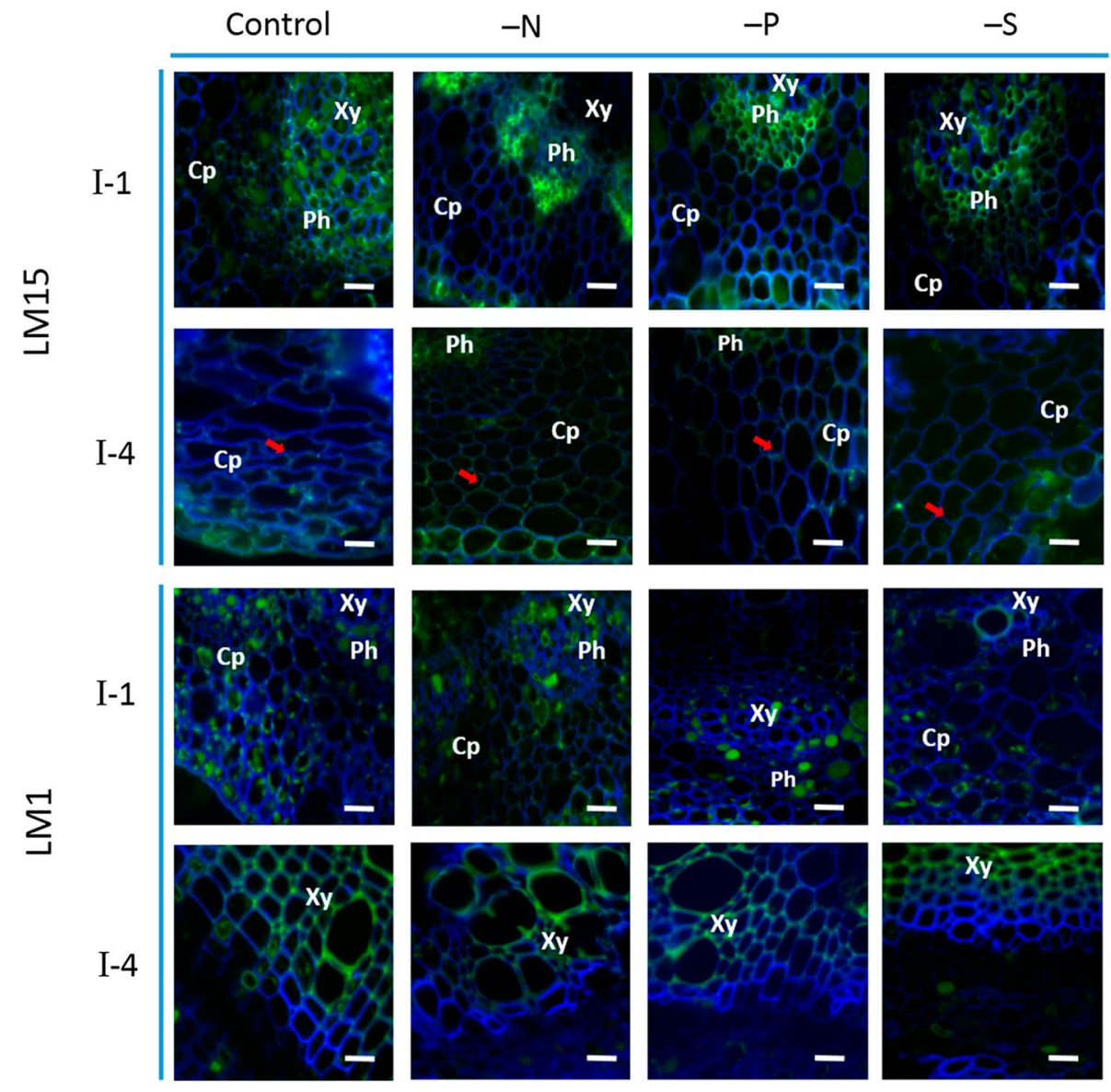

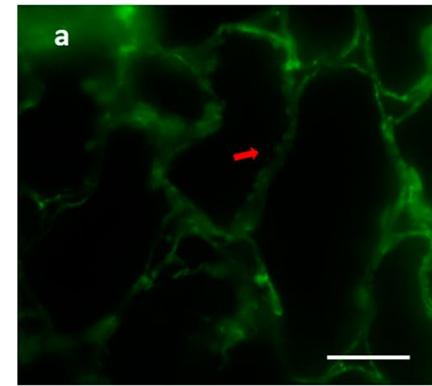
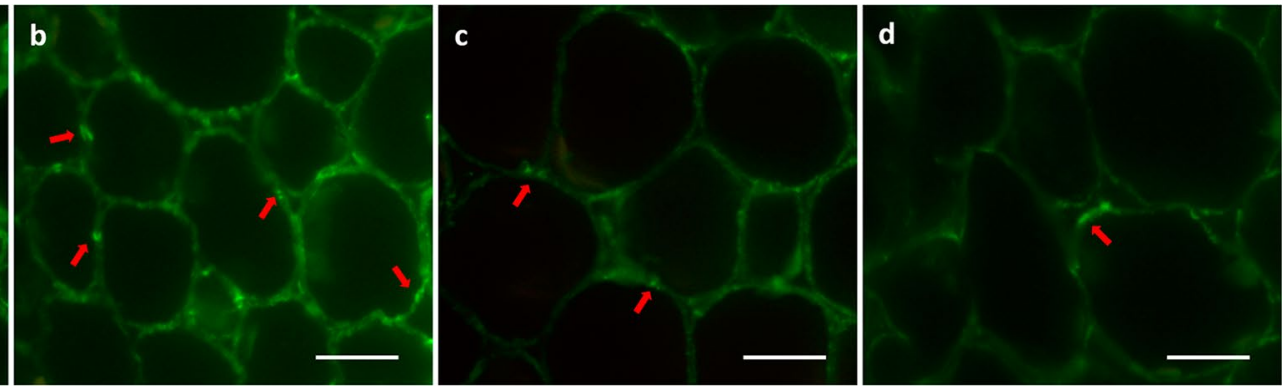

Fig. 7 In situ localization of the LM15 epitope in the cortical parenchyma of $V$. vinifera fourth (I-4) internode after 6 weeks growth in complete nutrient medium 8 (a) and in the absence of nitrogen (b),

compounds and protein synthesis, but also, indirectly, carbon metabolism. (Amtmann and Armengaud 2009; Crawford and Forde 2002; Frink et al. 1999). At the molecular level, most genes associated to amino acid or nucleotide biosynthesis are downregulated under nitrogen deficiency (Scheible et al. 2004). Likewise, low sulfate supply leads to a decrease in amino acid synthesis in particular cysteine and methionine (Hoefgen and Nikiforova 2008). Studies performed by Hirai et al. (2004) with low N and S supply not only showed an alteration in amino acid content phosphorus (c) and sulfur (d). Arrows point to regions with increase accumulation of LM15 showing an uneven coating of XyG in the CW. Bar scale $=20 \mu \mathrm{m}$

but also a reduction in photosynthetic activity. Nikiforova et al. (2005) reported that sulfur-deficiency stress induces a mutual influence between sulfur and nitrogen assimilation, a lipid breakdown and an enhanced photorespiration response. A reduction in $\mathrm{P}$ availability leads to a general decrease in the levels of P-containing intermediates and cofactors, such as nucleotides (Morcuende et al. 2007). During severe $\mathrm{P}$ starvation the transcription of several genes is affected including those involved in $\mathrm{P}$ remobilization, $\mathrm{P}$ transport and anthocyanin biosynthesis (Misson et al. 
2005). Summing up, the impairment of primary metabolism by nitrogen (Fritz et al. 2006), phosphorus (Stewart et al. 2001) or sulfur (Nikiforova et al. 2003; Tavares et al. 2013), can result in accumulated carbon skeletons available for the synthesis of secondary carbon-rich metabolites including phenolic compounds and $\mathrm{CW}$ polymers.

The analysis of plant model systems in controlled experimental conditions provides useful tools to assess nutrient deficiency situations. The first indication of effects from $\mathrm{N}$, $\mathrm{P}$ or $\mathrm{S}$ deficiency on $V$. vinifera cuttings was acquired through the confirmation that grapevine growth was affected by the mineral depletion. The lower number of internodes observed for each mineral stress condition (Fig. 1), supports the primary role of these major nutrients in plant development and metabolism and agrees with previous reports (Tschoep et al. 2009; Wu et al. 2003). The reduction of the number of internodes along with increased length of I-4 observed in shoots developed under $-\mathrm{N}$ was also observed by Triplett et al. (1981) in Phaseolus. Likewise, the observed alterations in xylem vessel area and form under $-\mathrm{N}$ (Table 1) corresponds with previous reports. Nitrogen effects on xylem morphology have been suggested to result from changes in cell elongation and expansion (Cooke et al. 2003; Pitre et al. 2010; Plavcová et al. 2012). We observed that longer internodes were formed under $-\mathrm{N}$ conditions together with an increase in pectins with low methyl-esterification but a significant decrease in the potential of those pectins to form calcium bridges in young expanding internodes (Table 2). This combination can promote the activity of pectolytic enzymes, reducing of the molecular weight of pectic polymers and leading to expansion (Xiao et al. 2014). The alteration of grapevine cell morphology was also observed in callus tissues in response to nitrogen and phosphorus deficiency (Fernandes et al. 2016).

The impairment of cellulose deposition in organized tissues which was more pronounced in older internodes (Fig. 2; Table 2) and agrees with previous observations in dedifferentiated material (Fernandes et al. 2013). However, cellulose, although present in low concentration, provides mechanical strength for load bearing (Tenhaken 2015). In view of the importance of the $\mathrm{CW}$ for survival and adaption to environmental constrains, plants are equipped with compensatory alternative mechanisms to reinforce their CWs when the biosynthesis or deposition of a given component is impaired (Pilling and Höfte 2003; Wolf et al. 2012). Our results agree with such assumption.

The increased pectin amounts with a lower degree of esterification and the higher proportion of accessible arabinose-rich chains disclosed under $-\mathrm{N}$ and $-\mathrm{P}$ (Figs. 4, 5; Table 2) are in agreement with our previously, observations in $V$. vinifera callus tissues (Fernandes et al. 2013), where an alteration in the degree of methyl-esterification occurred in response to nitrogen stress. This modification may occur localized to specific cells types and specific domains within the pectic chain, and is often developmentally regulated (Albersheim et al. 2010). PAM1 binds to long unesterified stretches of HG (regions of 30 contiguous unesterified HG) in a conformational dependent manner (Willats et al. 1999). PAM1 label was detected on the cell corners (Fig. 4). The occurrence of PAM1 epitopes within the $\mathrm{CW}$ junctions indicates that these $\mathrm{HG}$ domains have a role associated with cell adhesion at cell junctions (Willats et al. 2001). Pectins can serve as mechanical tethers between cellulose microfibrils (Park and Cosgrove 2012; Peaucelle et al. 2012; Wang et al. 2012). Within the pectic family, RGs-I are highly heterogeneous and rich in neutral side chains (Caffall and Mohnen 2009). The increased accumulation of different arrangement of 1,5-arabinan epitopes in the $\mathrm{CW}$ of recently and later formed internodes (Fig. 5; Table 2) can reflect a compensatory mechanism to cope with lower cellulose content. Apparently, in I-1, RG-I is more branched compered to I-4 that have a more linearized arabinan. Arabidopsis cellulose synthase mutant (MUR10/CesA7) showed an increase in pectic arabinan content in response to the impaired cellulose biosynthesis (Bosca et al. 2006). Likewise, under water deficit, Harholt et al. (2010) observed that RG-I arabinosyl side chains could work as plasticizers in CWs that undergo large physical remodeling to, in this way, reinforce their structure. CWs from callus growing under nitrogen and phosphorus depletion were also richer in tightly-attached arabinose-containing polysaccharides (Fernandes et al. 2013).

Pectin de-esterification can generate junction zones created by ordered, side-by-side associations of specific sequences of GalA linked through electrostatic and ionic bonding of carboxyl groups in the presence of calcium. In that circumstances, according to the well-known 'egg-box' model (Morris et al. 1982), a pectin gelation may occur (Jarvis 1984). Therefore, the observed increase of pectic chains linked by calcium ions in I-4 CWs developing under $-\mathrm{N}$, revealed by higher $2 \mathrm{~F} 4$ labelling (Liners et al. 1989), suggests additional CW stiffening (Michelli 2001) and reduced CW extensibility (Pelletier et al. 2010), which could explain the lower xylem vessel area observed under this condition (Table 1).

Hemicelluloses play an important role in the wall and as major class in dicots, $\mathrm{XyG}$, can influence its characteristics. Also under nitrogen deficiency, the significant increase in the amounts of $\mathrm{XyG}$ detected in the $\mathrm{CW}$ can be explained as a mechanism to reinforce the $\mathrm{CW}$, via biosynthesis of new material or the establishment of new linkages (Pilling and Höfte 2003; Wolf et al. 2012). The Arabidopsis XyGdeficient mutant $(x x t 1 / x x t 2)$ showed more extensible CWs than wild-type, supporting the reinforcing role for $\mathrm{XyG}$ (Park and Cosgrove 2012). XyG was observed in different region in I-1 and I-4. In both internodes XyG was present 
in the phloem and in some cells of the xylem, as observed by Marcus et al. (2008). In addition to the presence of XyG in the vascular bundle, in I-4, this polysaccharide was also present in the parenchyma cells (Fig. 6). Moreover, in I-4, the distribution of LM15 labelling is not contiguous along the wall with some preferred points of accumulation, especially under $-\mathrm{N}$ (Fig. 7). These observations suggest that $\mathrm{XyG}$ distribution is developmental regulated. Cellulose microfibrils are not evenly coated with XyG but occurring in distinct $\mathrm{CW}$ domains and its structure can change during wall growth (Marcus et al. 2008). According to Ordaz-Ortiz et al. (2009), the localization pattern of the LM15 epitope may reflect the former edge of cell adhesion planes/intercellular space. The labelling pattern observed here may also be related to the "biomechanical hotspots" theory proposed by Park and Cosgrove (2012, 2015), where increased detection of $\mathrm{XyG}$ in some regions may be the result of the closely intertwine with cellulose at limited sites.

The lower amount of extensins incorporated in the wall observed resulting from growth under $-\mathrm{N}$ and $-\mathrm{P}$ conditions (Fig. 6; Table 2) can also contribute to compromise the $\mathrm{CW}$ structure. These hydroxyproline-rich glycoproteins are essential for cell plate formation as revealed by Arabidopsis mutant impaired in AtEXT3 transcription (Hall and Cannon 2002) and it has been suggested that orderly assembly of pectins in the cell plate may involve covalent extensin-pectin cross-links (Nuñez et al. 2009; Qi et al. 1995). The fact that labelled extensin was maintained under -S may represent its contribution for attenuating the effects of -S mineral depletion.

Together our results support the assumption that grapevine organized tissues submitted to individual mineral stresses are impaired in specific CW components and suffer a reorganization of their deposition, in particular for pectin methyl-esterification and $\mathrm{XyG}$ degree and pattern, promoting a compensatory stiffening of the wall. The nutrient stress do not affected evenly all plant tissues. Mature internodes (I-4) showed a more pronounced reduction in cellulose and therefore an associated increase in $\mathrm{Ca}^{2+}$ linked pectins and XyGs. Confirming a similar mechanism observed in callus tissues (Fernandes et al. 2013), our results highlight that $V$. vinifera used different strategies to overcome the adverse effects that mineral stress imposed at the CW level, depending on the severity perceived and its biological role. Due to its vital role on plant metabolism nitrogen affects more dramatically the CW.

\footnotetext{
Acknowledgments The research was funded by Fundação para a Ciência e a Tecnologia (FCT) to CBAA (PestOE/AGR/UI0240/2011) and LEAF (Linking Landscape, Environment, Agriculture and Food) and Grant SFRH/BD/64047/2009 to JCF. The authors are pleased to acknowledge Prof ${ }^{\mathrm{a}}$. Leonor Morais and Vera Inácio for assistance in the fixation procedures and Eng ${ }^{\mathrm{a}}$. Teresa Quilhó for her support in the preparation of cross-sections.
}

\section{References}

Albersheim P, Darvill A, Roberts K, Sederoff R, Staehelin A (2010) Plant cell walls: from chemistry to biology. Garland Science, New York

Amtmann A, Armengaud P (2009) Effects of N, P, K and S on metabolism: new knowledge gained from multi-level analysis. Curr Opin Plant Biol 12:275-283. doi:10.1016/j.pbi.2009.04.014

Bosca S, Barton CJ, Taylor NG, Ryden P, Neumetzler L, Pauly M, Roberts K, Seifert GJ (2006) Interactions between MUR10/ CesA7 dependent secondary cellulose biosynthesis and primary cell wall structure. Plant Physiol 142:1353-1363. doi:10.1104/ pp.106.087700

Braidwood L, Breuer C, Sugimoto K (2014) My body is a cage: mechanisms and modulation of plant cell growth. New Phytol 201:388-402. doi:10.1111/nph.12473

Brashline L, Li S, Gu Y (2014) The trafficking of the cellulose synthase complex in higher plants. Ann Bot (Lond) 114:1059-1067. doi:10.1093/aob/mcu040

Caffall KH, Mohnen D (2009) The structure, function, and biosynthesis of plant cell wall pectic polysaccharides. Carbohydr Res 344:1879-1900. doi:10.1016/j.carres.2009.05.021

Cannon MC, Terneus K, Hall Q, Tan L, Wang Y, Wegenhart BL, Chen L, Lamport DT, Chen Y, Kieliszewski MJ (2008) Self-assembly of the plant cell wall requires an extensin scaffold. Proc Natl Acad Sci USA 105:2226-2231. doi:10.1073/pnas.0711980105

Cavalier DM, Lerouxel O, Neumetzler L, Yamauchi K, Reinecke A, Freshour G, Zabotina OA, Hahn MG, Burgert I, Pauly M, Raikhel NV, Keegstra K (2008) Disruption of two Arabidopsis thaliana xylosyltransferase genes results in plants deficient in xyloglucan, a major primary cell wall component. Plant Cell 20:1519-1537. doi:10.1105/tpc.108.059873

Coimbra S, Almeida J, Junqueira V, Costa ML, Pereira LG (2007) Arabinogalactan proteins as molecular markers in Arabidopsis thaliana sexual reproduction. J Exp Bot 58:4027-4035. doi:10.1093/jxb/erm259

Cooke JEK, Brown KA, Wu R, Davis JM (2003) Gene expression associated with $\mathrm{N}$-induced shifts in resource allocation in poplar. Plant Cell Environ 26:757-770. doi:10.1046/j.1365-3040.2003.01012.x

Cosgrove DJ (2000) Expansive growth of plant cell walls. Plant Physiol Biochem 38:109-124. doi:10.1016/S0981-9428(00)00164-9

Cosgrove DJ (2005) Growth of the plant cell wall. Nat Rev Mol Cell Biol 6:850-861

Cosgrove DJ, Jarvis MC (2012) Comparative structure and biomechanics of plant primary and secondary cell walls. Front Plant Sci 3:204. doi:10.3389/fpls.2012.00204

Crawford NM, Forde BG (2002) Molecular and developmental biology of inorganic nitrogen nutrition. In: Meyerowitz E, Somerville C (eds) The arabidopsis book. American Society of Plant Biologists, Rockville

Fernandes JC, García-Angulo P, Goulao LF, Acebes JL, Amâncio S (2013) Mineral stress affects the cell wall composition of grapevine (Vitis vinifera L.) callus. Plant Sci 205-206:111-120. doi:10.1016/j.plantsci.2013.01.013

Fernandes JC, Goulao LF, Amâncio S (2016) Regulation of cell wall remodeling in grapevine (Vitis vinifera L.) callus under individual mineral stress deficiency. J Plant Physiol 190:95-105. doi:10.1016/j.jplph.2015.10.007

Frink CR, Waggoner PE, Ausubel JH (1999) Nitrogen fertilizer: retrospect and prospect. Proc Natl Acad Sci USA 96:1175-1180. doi:10.1073/pnas.96.4.1175

Fritz C, Palacios-Rojas N, Feil R, Stitt M (2006) Regulation of secondary metabolism by the carbon-nitrogen status in tobacco: nitrate inhibits large sectors of phenylpropanoid metabolism. Plant J 46:533-548. doi:10.1111/j.1365-313X.2006.02715.x 
Hall Q, Cannon MC (2002) The cell wall hydroxyproline-rich glycoprotein RSH is essential for normal embryo development in Arabidopsis. Plant Cell 14:1161-1172. doi:10.1105/tpc.010477

Harholt J, Suttangkakul A, Vibe Scheller H (2010) Biosynthesis of pectin. Plant Physiol 153:384-395. doi:10.1104/pp.110.156588

Hijazi M, Velasquez SM, Jamet E, Estevez JM, Albenne C (2014) An update on post-translational modifications of hydroxyproline-rich glycoproteins: toward a model highlighting their contribution to plant cell wall architecture. Front Plant Sci 5:395. doi:10.3389/fpls.2014.00395

Hirai MY, Yano M, Goodenowe DB, Kanaya S, Kimura T, Awazuhara M, Arita M, Fujiwara T, Saito K (2004) Integration of transcriptomics and metabolomics for understanding of global responses to nutritional stresses in Arabidopsis thaliana. Proc Natl Acad Sci USA 101:10205-10210. doi:10.1073/pnas.0403218101

Hoefgen R, Nikiforova VJ (2008) Metabolomics integrated with transcriptomics: assessing systems response to sulfur-deficiency stress. Physiol Plant 132:190-198. doi:10.1111/j.1399-3054.2007.01012.x

Jarvis MC (1984) Structure and properties of pectin gels in plant cell walls. Plant Cell Environ 7:153-164. doi:10.1111/1365-3040. ep11614586

Knight H, Knight MR (2001) Abiotic stress signaling pathways: specificity and cross-talk. Trends Plant Sci 6:262-267. doi:10.1016/ S1360-1385(01)01946-X

Knox JP (2008) Revealing the structural and functional diversity of plant cell walls. Curr Opin Plant Biol 11:308-313. doi:10.1016/j. pbi.2008.03.001

Lamport DT, Kieliszewski MJ, Chen Y, Cannon MC (2011) Role of the extensin superfamily in primary cell wall architecture. Plant Physiol 156:11-19. doi:10.1104/pp.110.169011

Lee KJD, Marcus SE, Knox JP (2011) Cell wall biology: perspectives from cell wall imaging. Mol Plant 4:212-219. doi:10.1093/mp/ ssq075

Liners F, Letesson JJ, Didembourg C, Van Cutsem P (1989) Monoclonal antibodies against pectin: recognition of a conformation induced by calcium. Plant Physiol 91:1419-1424. doi:10.1104/ pp.91.4.1419

Lionetti V, Raiola A, Camardella L, Giovane A, Obel N, Pauly M, Favaron F, Cervone F, Bellincampi D (2007) Overexpression of pectin methyl-esterase inhibitors in Arabidopsis restricts fungal infection by Botrytis cinerea. Plant Physiol 143:1871-1880. doi: $10.1104 /$ pp. 106

Liu H, Ma Y, Chen N, Guo S, Liu H, Guo X, Chong K, Xu Y (2014) Overexpression of stress-inducible OsBURP16, the beta-subunit of polygalacturonase 1 , decreases pectin contents and cell adhesion, and increases abiotic stress sensitivity in rice. Plant Cell Environ 37:1144-1158. doi:10.1111/pce.12223

Marcus SE, Verhertbruggen Y, Hervé C, Ordaz-Ortiz JJ, Farkas V, Pedersen HL, Willats WGT, Knox JP (2008) Pectic homogalacturonan masks abundant sets of xyloglucan epitopes in plant cell walls. BMC Plant Biol 8:60. doi:10.1186/1471-2229-8-60

Michelli F (2001) Pectin methylesterases: cell wall enzymes with important roles in plant physiology. Trends Plant Sci 6:414-419. doi:10.1016/S1360-1385(01)02045-3

Misson J, Raghothama KG, Jain A, Jouhet J, Block MA, Bligny R et al (2005) A genome-wide transcriptional analysis using Arabidopsis thaliana Affymetrix gene chips determined plant responses to phosphate deprivation. Proc Natl Acad Sci USA 102:11934-11939. doi:10.1073/pnas.0505266102

Moller I, Marcus SE, Haeger A, Verhertbruggen Y, Verhoef R, Schols H, Mikklesen JD, Knox JP, Willats W (2008) High-throughput screening of monoclonal antibodies against plant cell wall glycans by hierarchial clustering of their carbohydrate microarray binding profiles. Glycoconjug J 25:37-48. doi:10.1007/s10719-007-9059-7
Morcuende R, Bari R, Gibon Y, Zheng W, Pant BD, Bläsing O, Usadel B, Czechowski T, Udvardi MK, Stitt M, Scheible WR (2007) Genome-wide reprogramming of metabolism and regulatory networks of Arabidopsis in response to phosphorus. Plant Cell Environ 30:85-112. doi:10.1111/j.1365-3040.2006.01608.x

Morris ER, Powell DA, Gidley MJ, Rees DA (1982) Conformations and interactions of pectins: I. Polymorphism between gel and solid states of calcium polygalacturonate. J Mol Biol 155:507516. doi:10.1016/0022-2836(82)90484-3

Muszyńska A, Jarocka K, Kurczynska EU (2014) Plasma membrane and cell wall properties of an aspen hybrid (Populus tremula $\times$ tremuloides) parenchyma cells under the influence of salt stress. Acta Physiol Plant 36:1155-1165. doi:10.1007/ s11738-014-1490-3

Nic-Can G, Hernández-Castellano S, Kú-González A, Loyola-Vargas VM, De-la-Peña C (2013) An efficient immunodetection method for histone modifications in plants. Plant Methods 9:47. doi:10.1186/1746-4811-9-47

Nikiforova V, Freitag J, Kempa S, Adamik M, Hesse H, Hoefgen R (2003) Transcriptome analysis of sulfur depletion in Arabidopsis thaliana: interlacing of biosynthetic pathways provides response specificity. Plant J 33:633-650. doi:10.1021/jf902162t

Nikiforova VJ, Kopka J, Tolstikov V, Fiehn O, Hopkins L, Hawkesford MJ, Hesse H, Hoefgen R (2005) Systems rebalancing of metabolism in response to sulfur deprivation, as revealed by metabolome analysis of Arabidopsis plants. Plant Physiol 138:304-318. doi:10.1104/pp.104.053793

Nuñez A, Fishman ML, Fortis LL, Cooke PH, Hotchkiss ATJ (2009) Identification of extensin protein associated with sugar beet pectin. J Agric Food Chem 57:10951-10958. doi:10.1021/jf902162t

Ordaz-Ortiz JJ, Marcus SE, Knox JP (2009) Cell wall microstructure analysis implicates hemicellulose polysaccharides in cell adhesion in tomato fruit pericarp parenchyma. Mol Plant 2:910-921. doi: $10.1093 / \mathrm{mp} / \mathrm{ssp} 049$

Park YB, Cosgrove DJ (2012) A revised architecture of primary cell walls based on biomechanical changes induced by substrate-specific endoglucanases. Plant Physiol 158:1933-1943. doi:10.1104/pp.111.192880

Park YB, Cosgrove DJ (2015) Xyloglucan and its interactions with other components of the growing cell wall. Plant Cell Physiol 56:180-194. doi:10.1093/pcp/pcu204

Pattathil S, Avci U, Baldwin D, Swennes AG, McGill JA, Popper Z, Bootten T, Albert A, Davis RH, Chennareddy C, Dong R, O'Shea B, Rossi R, Leoff C, Freshour G, Narra R, O'Neil M, York WS, Hahn MG (2010) A comprehensive toolkit of plant cell wall glycan-directed monoclonal antibodies. Plant Physiol 153:514-525. doi:10.1104/pp.109.151985

Peaucelle A, Louvet R, Johansen JN, Hofte H, Laufs P, Pelloux J, Mouille G (2008) Arabidopsis phyllotaxis is controlled by the methyl-esterification status of cell-wall pectins. Curr Biol 18:1943-1948. doi:10.1016/j.cub.2008.10.065

Peaucelle A, Braybrook S, Hofte H (2012) Cell wall mechanics and growth control in plants: the role of pectins revisited. Front Plant Sci 3:121. doi:10.3389/fpls.2012.00121

Pelletier S, Orden J, Wolf S, Vissenberg K, Delacourt J, Ndong YA, Pelloux J, Bischoff V, Urbain A, Mouille G, Lemonnier G, Renou JP, Hofte H (2010) A role for pectin de-methylesterification in a developmentally regulated growth acceleration in dark-grown Arabidopsis hypocotyls. New Phytol 188:726-739. doi:10.1111/j.1469-8137.2010.03409.x

Pelloux J, Rusterucci C, Mellerowicz EJ (2007) New insights into pectin methyl-esterase structure and function. Trends Plant Sci 12:267-277. doi:10.1016/j.tplants.2007.04.001

Pilling E, Höfte H (2003) Feedback from the wall. Curr Opin Plant Biol 6:611-616. doi:10.1016/j.pbi.2003.09.004 
Pitre FE, Lafarguette F, Boyle B, Pavy N, Caron S, Dallaire N, Poulin PL, Ouellet M, Morency MJ, Wiebe N, Ly Lim E, Urbain A, Mouille G, Cooke JE, Mackay JJ (2010) High nitrogen fertilization and tension wood induction have overlapping effects on wood formation in poplar but invoke largely distinct molecular pathways. Tree Physiol 30:1273-1289. doi:10.1093/treephys/ tpq073

Plavcová L, Hacke UG, Almeida-Rodriguez AM, Li E, Douglas CJ (2012) Gene expression patterns underlying changes in xylem structure and function in response to increased nitrogen availability in hybrid poplar. Plant, Cell Environ 36:186-199. doi:10.1111/j.1365-3040.2012.02566.x

Popper ZA, Fry SC (2008) Xyloglucan-pectin linkages are formed intraprotoplasmically, contribute to wall-assembly, and remain stable in the cell wall. Planta 227:781-794. doi:10.1007/ s00425-007-0656-2

Qi XY, Behrens BX, West PR, Mort AJ (1995) Solubilization and partial characterization of extensin fragments from cell walls of cotton suspension-cultures, evidence for a covalent cross-link between extensin and pectin. Plant Physiol 108:1691-1701. doi:10.1104/pp.108.4.1691

Ralet MC, Tranquet O, Poulain D, Moïs A, Guillon F (2010) Monoclonal antibodies to rhamnogalacturonan I backbone. Planta 231:1373-1383. doi:10.1007/s00425-010-1116-y

Ringli C (2010) The hydroxyproline-rich glycoprotein domain of the Arabidopsis LRX1 requires Tyr for function but not for insolubilization in the cell wall. Plant $\mathrm{J}$ 63:662-669. doi:10.1111/j.1365-313X.2010.04270.x

Scheible WR, Morcuende R, Czechowski T, Fritz C, Osuna D, PalaciosRojas N, Schindelasch D, Thimm O, Udvardi MK, Stitt M (2004) Genome-wide reprogramming of primary and secondary metabolism, protein synthesis, cellular growth processes, and the regulatory infrastructure of Arabidopsis in response to nitrogen. Plant Physiol 136:2483-2499. doi:10.1104/pp.104.047019

Scheller HV, Ulvskov P (2010) Hemicelluloses. Ann Rev Plant Biol 61:263-289. doi:10.1146/annurev-arplant-042809-112315

Showalter AM (1993) Structure and function of plant cell wall proteins. Plant Cell 5:9-23. doi:10.1105/tpc.5.1.9

Smallwood M, Martin H, Knox JP (1995) An epitope of rice threonine- and hydroxyproline-rich glycoprotein is common to cell wall and hydrophobic plasma membrane glycoproteins. Planta 196:510-522. doi:10.1007/BF00203651

Stewart AJ, Chapman W, Jenkins GI, Graham I, Martin T, Crozier A (2001) The effect of nitrogen and phosphorus deficiency on flavonol accumulation in plant tissues. Plant Cell Environ 24:11891197. doi:10.1046/j.1365-3040.2001.00768.x

Tavares S, Vesentini D, Fernandes JC, Ferreira RB, Laureano O, Ricardo-Da-Silva JM, Amâncio S (2013) Vitis vinifera secondary metabolism as affected by sulfate depletion: diagnosis through phenylpropanoid pathway genes and metabolites. Plant Physiol Biochem 66:118-126. doi:10.1016/j.plaphy.2013.01.022

Tenhaken T (2015) Cell wall remodeling under abiotic stress. Front Plant Sci 5:771. doi:10.3389/fpls.2014.00771

Thompson DS (2005) How do cell walls regulate plant growth? J Exp Bot 56:2275-2285. doi:10.1093/jxb/eri247

Triplett EW, Heitholt JJ, Evensen KB, Blevins DG (1981) Increase in internode length of Phaseolus lunatus L. caused by inoculation with a nitrate reductase-deficient strain of Rhizobium sp. Plant Physiol 67:1-4

Tschoep H, Gibon Y, Carillo P, Armengaud P, Szecowka M, NunesNesi A, Fernie AR, Koehl K, Stitt M (2009) Adjustment of growth and central metabolism to a mild but sustained nitrogen limitation in Arabidopsis. Plant Cell Environ 32:300-318. doi:10.1111/j.1365-3040.2008.01921.x

Velasquez SM, Ricardi MM, Dorosz JG, Fernandez PV, Nadra AD, Pol-Fachin L, Egelund J, Gille S, Harholt J, Ciancia M, Verli H, Pauly M, Bacic A, Olsen CE, Ulvskov P, Petersen BL (2011) O-glycosylated cell wall proteins are essential in root hair growth. Science 17:1401-1403. doi:10.1126/science.1206657

Velasquez SM, Salgado Salter J, Petersen BL, Estevez JM (2012) Recent advances on the post-translational modifications of EXTs and their roles in plant cell walls. Front Plant Sci 3:93. doi: $10.3389 /$ fpls.2012.00093

Wang T, Zabotina O, Hong M (2012) Pectin-cellulose interactions in the Arabidopsis primary cell wall from two-dimensional magicangle-spinning solid-state nuclear magnetic resonance. Biochemistry 51:9846-9856. doi:10.1021/bi3015532

Willats WG, Marcus SE, Knox JP (1998) Generation of monoclonal antibody specific to $(1 \rightarrow 5)$-alpha-L-arabinan. Carbohydr Res 308:149-152. doi:10.1016/S0008-6215(98)00070-6

Willats WG, Gilmartin PM, Mikkelsen JD, Knox JP (1999) Cell wall antibodies without immunization: generation and use of de-esterified homogalacturonan block-specific antibodies from a naive phage display library. Plant $\mathrm{J}$ 18:57-65. doi:10.1046/j.1365-313X.1999.00427.x

Willats WGT, Orfila C, Limberg G, Buchholt HC, van Alebeek GJWM, Voragen AGJ, Marcus SE, Christensen TMIE, Mikkelsen JD, Murray BS, Knox JP (2001) Modulation of the degree and pattern of methyl-esterification of pectic homogalacturonan in plant cell walls. Implications for pectin methyl esterase action, matrix properties, and cell adhesion. J Biol Chem 276:1940419413. doi:10.1074/jbc.M011242200

Wolf S, Hematy K, Hoefte H (2012) Growth control and cell wall signaling in plants. Ann Rev Plant Biol 63:381-407. doi:10.1146/annurev-arplant-042811-105449

Wu P, Ma L, Hou X, Wang M, Wu Y, Liu F, Deng XW (2003) Phosphate starvation triggers distinct alterations of genome expression in Arabidopsis roots and leaves. Plant Physiol 132:1260 1271. doi:10.1104/pp.103.021022

Xiao C, Somerville C, Anderson CT (2014) Polygalacturonase involved in expansion1 functions in cell elongation and flower development in Arabidopsis. Plant Cell 26:1018-1035. doi:10.1105/tpc. 114.123968

Zabotina OA, Avci U, Cavalier D, Pattathil S, Chou YH, Eberhard S, Danhof L, Keegstra K, Hahn MG (2012) Mutations in multiple XXT genes of Arabidopsis reveal the complexity of xyloglucan biosynthesis. Plant Physiol 159:1367-1384. doi:10.1104/ pp.112.198119

Zykwinska A, Gaillard C, Buléon A, Pontoire B, Garnier C, Thibault JF, Ralet MC (2007) Assessment of in vitro binding of isolated pectic domains to cellulose by adsorption isotherms, electron microscopy and X-ray diffraction methods. Biomacromolecule 8:223-232. doi:10.1021/bm060292h 